\title{
Assessment of tree species resistance to air pollution around a metal-scrap recycling factory using air pollution tolerance index and anticipated performance index
}

\author{
S. Oyedeji ${ }^{1} *$, O.O. Agboola ${ }^{2}$, J.K. Oyekunle ${ }^{1}$, D.A. Animasaun ${ }^{1}$ and \\ P.O. Fatoba ${ }^{1}$ \\ ${ }^{1}$ Department of Plant Biology, University of Ilorin, 240003, Ilorin, Nigeria \\ ${ }^{2}$ Department of Botany, University of Lagos, Akoka, Lagos, Nigeria. \\ *Correspondence: oyedeji.s@unilorin.edu.ng; (iD https://orcid.org/0000-0001-7357-1152
}

Received: 23 ${ }^{\text {rd }}$ March 2018, Revised: 31 ${ }^{\text {th }}$ December 2018, Accepted: 05 ${ }^{\text {th }}$ March 2019

\begin{abstract}
Air pollution is one of the major global tribulations in many developing cities around the world. This study evaluates pollution resistance of Terminalia catappa, Anacardium occidentale and Tectona grandis growing around a metal scrap-recycling factory in Osun state, Nigeria using air pollution tolerance index (APTI) and anticipated performance index (API) with the view of recommending the species for greenbelt development in urban spaces. Biochemical parameters such as ascorbic acid, total chlorophyll content, foliar extract $\mathrm{pH}$ and relative water content were analyzed in fresh leaves harvested from the tree species growing around the metal-scrap recycling factory (ES) and a relatively unpolluted control site (CS). APTI and API were obtained from the results of biochemical variables. The results showed that biochemical parameters (ascorbic acid, total chlorophyll, foliar extract $\mathrm{pH}$ and relative water content) and APTI varied significantly $(p<0.05)$ among tree species and between the sites. The order of APTI varied as T. catappa (15.66) > A. occidentale (13.53) > T. grandis (13.17) with plants having a higher index at CS than at ES. All three-tree species showed intermediate tolerance but $T$. catappa and A. occidentale were assessed as good performers while $T$. grandis performed moderately in polluted sites. The study recommended T. catappa and A. occidentale over $T$. grandis for use in developing greenbelts in urban centres especially in highly polluted areas, such as the vicinity of factories.
\end{abstract}

Keywords: Atmospheric pollution, green belt development, pollution monitoring, tolerance.

\section{Introduction}

Pollution, especially atmospheric pollution, is one of the major problems arising from human population explosion and industrialization (Odilora et al. 
2006). It is true that industrialization improves the wealth of nations, but the degradation of environmental quality via pollution is a cause for concern. Most developing countries, especially those in sub-Saharan Africa, depend mainly on revenues from industries (Omoju 2014), hence their proliferation is considered a huge gain. In Nigeria for example, metal scrap-recycling is fast becoming a major activity due to increasing per capita consumption of steel and shortage of iron ore in the country. This has led to the proliferation of metal recycling factories in urban centres and suburbs, where waste and scavenged metals are rolled to steel (Ohamain 2013). These factories are becoming a cause for concern as their operations release toxic gases (such as sulphur and nitrogen oxides, carbon monoxide) and particles (such as sooth, metal particles and organic molecules) into the atmosphere.

Air pollutants represent a complex mixture of organic and inorganic substances of varying states and sizes that can enter tissues of living organisms in a number of ways (Thakar and Mishra 2010). Many plants are very sensitive to air pollutants which can damage their leaves, impair plant growth and limit primary productivity (Agrawal 1985, 2005, Thakar and Mishra 2010). Much experimental work has been conducted on the analysis of air pollutants effects on crops and vegetation at various levels ranging from biochemical to ecosystems levels (Hill 1971, Cavanagh et al. 2009, Gupta et al. 2011). Often times, plants exposed to pollutants experience changes in their biochemical functioning (such as those of ascorbic acid, chlorophyll and relative water contents) even before visible damage to leaves can be noticed (Liu and Ding 2008). These changes in plants serve as the basis for pollution monitoring (Prusty et al. 2005). Bio-monitoring of air pollution has been found to be extremely useful in detecting the kind and level of pollutants in the air with or without measurements (Prusty et al. 2005). Studies on air pollution impacts on vegetation have shown that it alters ascorbic acid content (Hoque et al. 2007) chlorophyll content (Flowers et al. 2007), leaf extract $\mathrm{pH}$ (Klumpp et al. 2000) and relative water content (Rao 1977).

These parameters separately produced conflicting results for same plant species (Han et al. 1995). However, the air pollution tolerance index (APTI) based on all four parameters has been used for identifying tolerance levels of plant species (Singh et al. 1991, Singh and Rao 1993, Liu and Ding 2008, Ogunkunle et al. 2015). Air Pollution Tolerance Index (APTI) is an inherent quality of plants to encounter air pollution stress which at present is a prime concern, particularly, in urban and industrial areas. The non-mobile (stationary) nature of plant species exposes them continuously to point source pollution. This makes air pollution impact on plants to be proportional to the intensity of pollution in the environment. APTI is a species-dependent attribute and expresses the inherent ability of a plant species to withstand stress emanating from pollution (Lohe et al. 2015). It also informs the public of the local ambient air pollution status and the potential risk it would impose, particularly on vulnerable groups such as children, old people and those with 
existing cardiovascular and respiratory diseases (Rajamanickam and Nagan 2018). Categorization of plants as sensitive or tolerant is determined by the level of biochemical parameters used to compute the APTI for a species.

Tolerant plant species are sinks and living filters minimizing air pollution impact by absorption, adsorption, detoxification, accumulation, and/ or metabolization without sustaining serious foliar damage or decline in growth in the face of pollution (Mondal et al. 2011). APTI determination thus provides a reliable method for screening a large number of plants with respect to their resistance and susceptibility to air pollutants. This study assesses air pollution resistance of Indian Almond (Terminalia catappa), Cashew (Anacardium occidentale) and Teak (Tectona grandis) growing around a metal scrap-recycling factory in Osun state, south-west Nigeria using their APTI and API with the view of recommending the species for greenbelt development in urban spaces.

\section{Material and Methods}

\subsection{Study area}

The study was carried out in March, 2017 on tree stands growing around Prism Steel Rolling Mill, a metal scrap-recycling factory located on latitude N07'52'42.6" and longitude E004'39'12.0" (Figure 1). The factory is situated along Ikirun-Osogbo expressway, Ikirun, Osun state. The factory became fully operational in 2012, and has since been recycling metal scraps into iron rods of 8, 12, 16, 20 and $32 \mathrm{~mm}$ in diameter of standard lengths. The scrap metals are conveyed to the factory from different parts of the country by heavy duty trailers. The pollution from metal smelting activities and those from exhaust fumes of trailers moving in and out of the factory make the study important. The prevailing climate in the site is distinctively tropical with annual rainfall of about $1400 \mathrm{~mm}$ and daily air temperature ranging from $23^{\circ} \mathrm{C}$ to $33^{\circ} \mathrm{C}$. The relative humidity is about $55 \%$ during the dry season and about $90 \%$ during the rainy season.

The study locations were classified into two zones: (a) the experimental site (ES) and (b) the control site (CS) which is an agricultural land about 30 $\mathrm{km}$ away from the experimental site (Figure 1).

\subsection{Sample collection}

Three tree species (Terminalia catappa L., Tectona grandis L.f. and Anacardium occidentale L.) established around the perimeter fencing of the experimental site and also found in the control site were used for the study. 
Tree stand selected for the study were less than 5 years old, and possess diameter of greater than $10 \mathrm{~cm}$ at breast height.

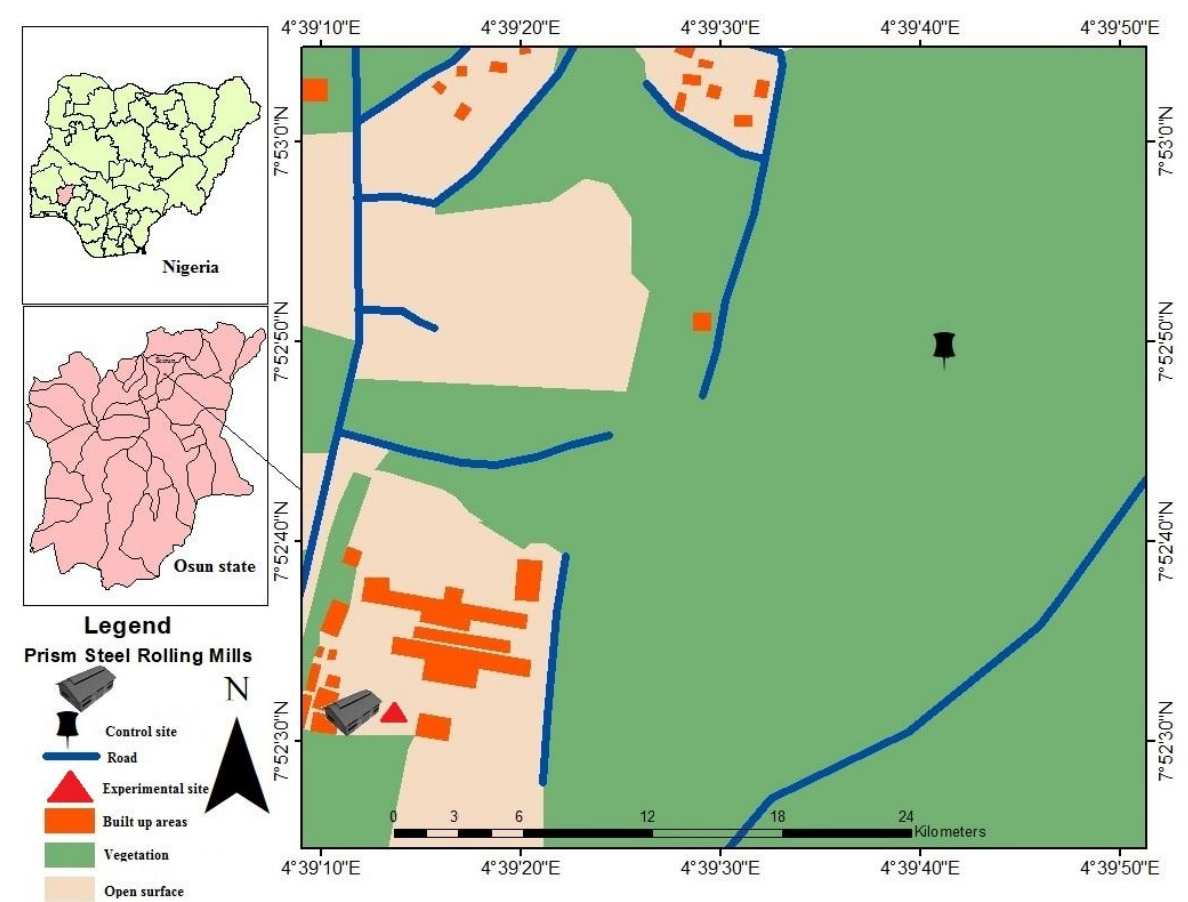

Fig. 1. Maps of Nigeria and Osun state showing the location of the experimental and control sites.

Matured fresh leaf samples ( $1 \mathrm{~kg}$ each) were collected in the morning from five selected stands of each tree species in the experimental site and control site. The leaf samples were immediately transferred to the laboratory for determination of the ascorbic acid, total chlorophyll content, leaf extract $\mathrm{pH}$ and relative water content (RWC).

Ascorbic acid (AA) content of leaves was determined using the spectrophotometric method (Begum and Harikrishna 2010). Total chlorophyll content was determined by the spectrophotometric method described by Arnon (1949). Leaf extract $\mathrm{pH}$ was determined using $2.5 \mathrm{~g}$ fresh leaf sample homogenized in $10 \mathrm{ml}$ distilled water using warring blender and read using a pre-calibrated digital pH meter (Orion Star Benchtop, Thermoscientific).

Relative water content (\% RWC) of leaves was determined using the method of Liu and Ding (2008). APTI was determined according to the method proposed by Singh and Rao (1983). Tree species were classified as sensitive, intermediate or tolerant based on APTI class proposed by Padmavathi et al. (2013). 


\subsection{Data analysis}

Two-way analysis of variance (ANOVA) was used to compare biochemical parameters and APTI for three tree species in the experimental site (ES) and control site (CS). Significant means were separated using Fisher's protected LSD at $\alpha$ level of 0.05 using SAS software 9.1.3 for Windows.

\subsection{Determination of anticipated performance index}

Average APTI values with relevant biological characters (including plant type and habit, canopy structure, laminar size, texture and hardiness) and socioeconomic character (economic value) grading (using + or -) were combined to obtain the anticipated performance index (API) for the tree species. Allotted points were scaled for grading based using the method of Prajapati and Tripathi (2008) as adopted by Ogunkunle et al. (2015).

\section{Results \& Discussion}

\subsection{Effect of air pollution on ascorbic acid}

Ascorbic acid is an antioxidant found in all growing plants. It positively influences resistance to environmental stresses including air pollution (Lima and Fernandez 2000, Mondal et al. 2011). The concentration of foliar ascorbic acid in the leaves varied significantly with tree species $\left(F_{2,24}=285.74 ; P<\right.$ $0.01)$ and site $\left(F_{1,24}=5.79 ; P=0.02\right)$. Terminalia catappa showed the highest concentration at ES $(2.47 \mathrm{mg} / \mathrm{g})$ and CS $(2.44 \mathrm{mg} / \mathrm{g})$, while Tectona grandis showed the lowest concentration of $1.86 \mathrm{mg} / \mathrm{g}$ and $1.76 \mathrm{mg} / \mathrm{g}$ respectively (Fig. 2a). The variation in foliar ascorbic acid concentrations among the trees species reflects species specificity to air pollution. There was no significant interaction between tree species and site $\left(F_{2,24}=1.02 ; P=0.38\right)$ for foliar ascorbic acid concentration (Table 1a). There was significant variation in the concentrations of ascorbic acid in Tectona grandis at ES and CS (Fig. 2a). This result is consistent with the findings of Ogunkunle et al. (2015) who also reported increases in AA in polluted areas. Increases in ascorbic acid in plants in polluted areas (such as around the metal recycling factory in this study) has been speculated to be favoured by increasing production of reactive oxygen species (ROS) (Mondal et al. 2011). Researchers are of the opinion that higher ascorbic acid content signals plant species tolerance against air pollution, especially exposure to sulphur dioxide (Varshney and Varshney 1984, Singare and Talpade 2012). 

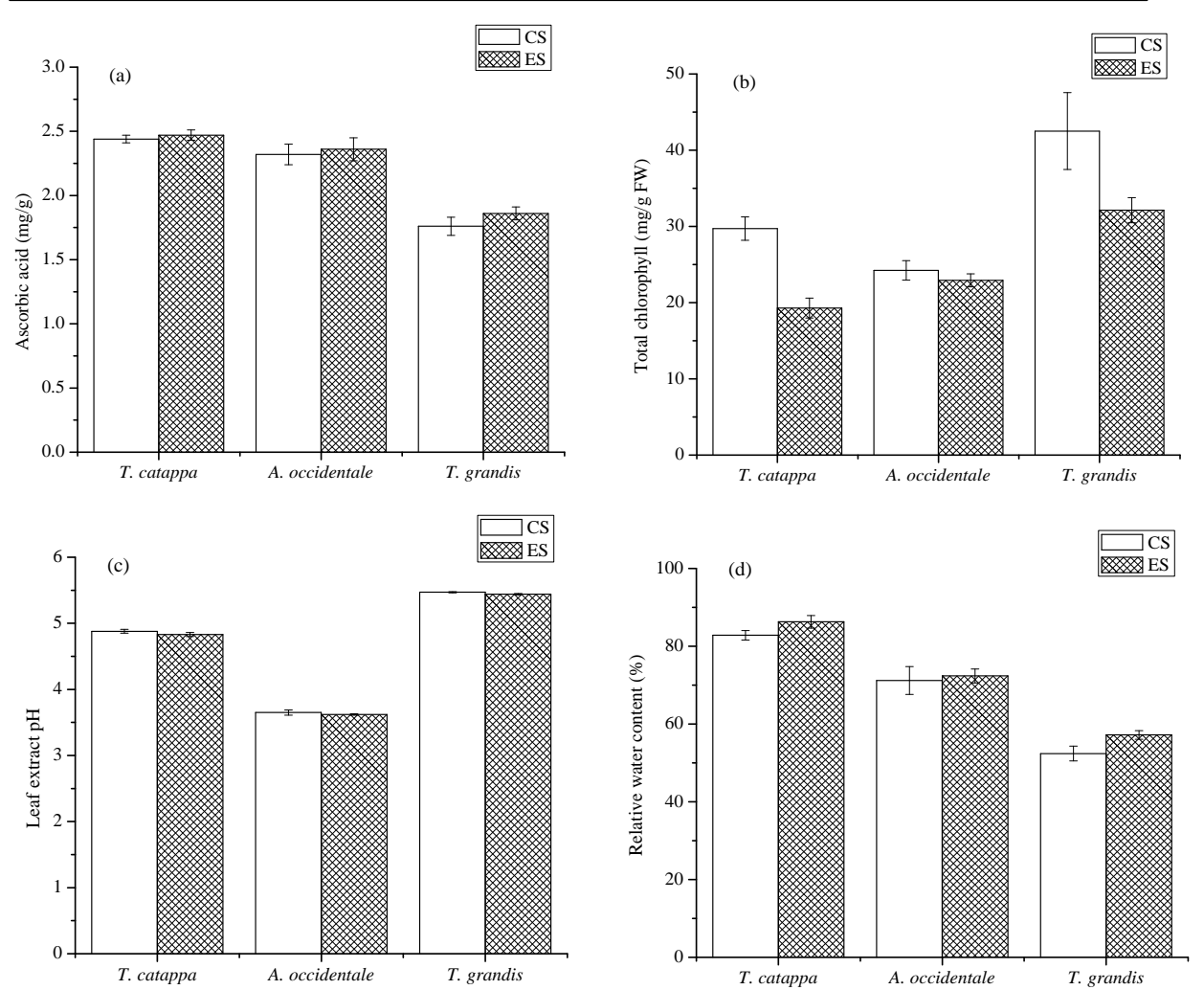

Fig 2. Ascorbic acid (a), total chlorophyll (b), leaf extract pH (c), and (d) relative water content of tree species around metal recycling factory and control site. Bars represent mean \pm standard deviations for $n=15$.

\subsection{Effect of air pollution on total chlorophyll}

Total chlorophyll concentration was significantly different between tree species $\left(F_{2,24}=101.98 ; P<0.01\right)$ and site $\left(F_{1,24}=70.48 ; P<0.01\right)$. There was also significant interaction between tree species and site $\left(F_{2,24}=11.98 ; P<\right.$ 0.01 ) (Table 1a) indicating that site condition affected the tree species differently. Tree species in CS had higher total chlorophyll than those at ES, except for Anacardium occidentale. Tectona grandis in CS had the highest concentration of total chlorophyll $(42.51 \mathrm{mg} / \mathrm{g})$ while $T$. catappa at ES had the lowest (19.30 mg/g) (Figure 2b). The higher chlorophyll content is the control site is consistent with the result of Gholami, et al. (2016) for tree species around polluted areas in Iran. Reduction in total chlorophyll concentrations in tree species growing around the factory supports the argument that chloroplast is the primary site of attack by air pollutants leading to the increase in chlorophyllase activity and resultant degradation of chlorophyll (Ninave, et al. 2001, Tripathi and Gautam 2007). 
Table 1a: F-statistics for biochemical parameters and ATPI of tree species in experimental site (around metal scrap recycling factory) and control site.

\begin{tabular}{|c|c|c|c|c|c|c|c|c|c|c|c|}
\hline \multirow{2}{*}{$\begin{array}{l}\text { Source of } \\
\text { variation }\end{array}$} & \multicolumn{3}{|c|}{ Ascorbic acid } & \multicolumn{2}{|c|}{ Total Chlorophyll } & \multicolumn{2}{|c|}{ pH } & \multicolumn{2}{|c|}{ RWC } & \multicolumn{2}{|c|}{ APTI } \\
\hline & $d f$ & $F$ & $P$-value & $F$ & $P$-value & $F$ & $P$-value & $F$ & $P$-value & $F$ & $P$-value \\
\hline Species & 2 & 285.74 & $<0.0001$ & 101.98 & $<0.0001$ & 16677.90 & 0.0002 & 536.01 & $<0.0001$ & 97.88 & $<0.0001$ \\
\hline Site & 1 & 5.79 & 0.0242 & 70.48 & $<0.0001$ & 18.87 & $<0.0001$ & 17.82 & 0.0003 & 45.69 & $<0.0001$ \\
\hline Site $\times$ species & 2 & 1.02 & 0.3774 & 11.91 & 0.0003 & 1.18 & 0.3232 & 2.02 & 0.1552 & 14.34 & $<0.0001$ \\
\hline Error & 24 & & & & & & & & & & \\
\hline
\end{tabular}

$d f=$ degrees of freedom. $F=$ F-ratio (Fisher's ratio); RWC = Relative water content; APTI = air pollution tolerance index.

Table 1b: Means of biochemical parameters and ATPI of tree species in experimental site (around metal scrap recycling factory) and control site.

\begin{tabular}{|c|c|c|c|c|c|c|}
\hline Factor & & Ascorbic acid & $\begin{array}{l}\text { Total } \\
\text { chlorophyll }\end{array}$ & Leaf extract pH & $\begin{array}{l}\text { Relative water } \\
\text { content }\end{array}$ & ATPI \\
\hline \multirow[t]{4}{*}{ Species } & $\begin{array}{l}\text { Terminalia } \\
\text { catappa }\end{array}$ & $2.46^{\mathrm{a}}$ & $24.51^{b}$ & $4.855^{\mathrm{b}}$ & $84.56^{\mathrm{a}}$ & $15.66^{\mathrm{a}}$ \\
\hline & $\begin{array}{c}\text { Anacardium } \\
\text { occidentale }\end{array}$ & $2.34^{\mathrm{b}}$ & $23.58^{\mathrm{b}}$ & $3.637^{c}$ & $71.78^{\mathrm{b}}$ & $13.53^{b}$ \\
\hline & Tectona grandis & $1.81^{\mathrm{c}}$ & $37.31^{\mathrm{a}}$ & $5.456^{\mathrm{a}}$ & $54.79^{c}$ & $13.17^{\mathrm{C}}$ \\
\hline & $\mathrm{LSD}_{0.05}$ & 0.0486 & 2.2189 & 0.0209 & 1.8829 & 0.3958 \\
\hline \multirow[t]{3}{*}{ Site } & CS & $2.17^{\mathrm{b}}$ & $32.15^{\mathrm{a}}$ & $4.67^{\mathrm{a}}$ & $68.81^{\mathrm{b}}$ & $14.65^{\mathrm{a}}$ \\
\hline & ES & $2.23^{\mathrm{a}}$ & $24.78^{\mathrm{b}}$ & $4.63^{\mathrm{b}}$ & $71.95^{\mathrm{a}}$ & $13.59^{\mathrm{b}}$ \\
\hline & $\mathrm{LSD}_{0.05}$ & 0.0595 & 1.8117 & 0.0171 & 1.5374 & 0.3231 \\
\hline
\end{tabular}

Means with different superscripted letter are significantly different at $P<0.05$ 
Table 2: Air pollution tolerance index (APTI) and class for tree species growing around a metal recycling factory (ES) and control site (CS).

\begin{tabular}{lllll}
\hline Tree species & CS & ES & Average & APTI class \\
\hline Terminalia catappa & $16.72 \pm 0.45^{\mathrm{a} \dagger}$ & $14.59 \pm 0.37^{\mathrm{a}}$ & 15.66 & Intermediate \\
Anacardium occidentale & $13.58 \pm 0.41^{\mathrm{b} \dagger}$ & $13.49 \pm 0.32^{\mathrm{b}}$ & 13.53 & Intermediate \\
Tectona grandis & $13.65 \pm 0.65^{\mathrm{b} \dagger}$ & $12.70 \pm 0.27^{\mathrm{c}}$ & 13.17 & Intermediate \\
\hline
\end{tabular}

Mean \pm SD with the same letter down a column are not significantly different at $P>0.05 .{ }^{\dagger}$ indicate significantly higher

APTI value between the sites (CS and ES)

Table 3: Anticipated performance index (API) grade and assessment for tree species around metal and steel recycling factory.

\begin{tabular}{|c|c|c|c|c|c|c|c|c|c|c|c|c|}
\hline \multirow[t]{2}{*}{ Tree species } & \multirow[t]{2}{*}{ APTI } & \multirow[t]{2}{*}{$\begin{array}{l}\text { Tree } \\
\text { habit }\end{array}$} & \multirow[t]{2}{*}{$\begin{array}{l}\text { Canopy } \\
\text { structure }\end{array}$} & \multirow{2}{*}{$\begin{array}{l}\text { Type } \\
\text { of } \\
\text { plant }\end{array}$} & \multicolumn{3}{|c|}{ Laminar structure } & \multirow[t]{2}{*}{$\begin{array}{l}\text { Economic } \\
\text { value }\end{array}$} & \multirow[t]{2}{*}{$\begin{array}{c}\text { Total } \\
+\end{array}$} & \multirow[t]{2}{*}{$\begin{array}{c}\% \\
\text { Score }\end{array}$} & \multicolumn{2}{|r|}{ API } \\
\hline & & & & & Size & Texture & Hardiness & & & & Grade & Assessment \\
\hline $\begin{array}{l}\text { Terminalia } \\
\text { catappa }\end{array}$ & +++ & ++ & ++ & - & + & + & + & + & 11 & 68.75 & 4 & Good \\
\hline $\begin{array}{l}\text { Anacardium } \\
\text { occidentale }\end{array}$ & ++ & + & ++ & + & + & + & + & ++ & 11 & 68.75 & 4 & Good \\
\hline Tectona grandis & ++ & ++ & + & - & ++ & + & - & + & 9 & 56.25 & 3 & Moderate \\
\hline
\end{tabular}

APTI = air pollution tolerance index. 


\subsection{Effect of air pollution on leaf extract pH}

Leaf extract $\mathrm{pH}$ varied significantly among the tree species $\left(F_{2,24}=16677.90\right.$; $P<0.01)$ and sites $\left(F_{1,24}=18.87 ; P<0.0001\right)$. There was no significant interaction between tree species and site $\left(F_{2,24}=1.18 ; P=0.32\right)$ for leaf extract $\mathrm{pH}$ (Table 1a). Plants at ES showed significantly lower leaf $\mathrm{pH}$ than in CS (Table 1b). Tectona grandis at CS showed the highest $\mathrm{pH}(5.47)$ while $A$. occidentale at ES showed the least (3.62). Terminalia catappa showed the highest reduction in $\mathrm{pH}$ (4.88 to 4.83) (Fig. 2c). Lower leaf extract $\mathrm{pH}$ in plants at ES may be due to the presence of acidic pollutants such as $\mathrm{SO}_{2}$ and $\mathrm{NO}_{\mathrm{x}}$ in air vicinity of the factory. Scholz and Reck (1977) and Escobedo, et al. (2008) also reported that acidic pollutants have the potentials to lower leaf extract $\mathrm{pH}$. Pollutants such as $\mathrm{SO}_{2}$ and $\mathrm{NO}_{\mathrm{x}}$ diffuse through leaf openings (stomata) and react with cellular water to form acid radicals in leaf matrix (Mondal et al. 2011).

\subsection{Effect of air pollution on relative water content}

Relative water content (RWC) was significantly different among the tree species $\left(F_{2,24}=52.64 ; P<0.01\right)$ and site $\left(F_{1,24}=17.82 ; P<0.01\right)$ (Table $\left.1 \mathrm{a}\right)$. The decreasing order of RWC was T. catappa $>$ A. occidentale $>$ T. grandis and was consistent for ES and CS (Fig. 2d). RWC ranges were $50.40 \%-$ 84.05\% at CS and 56.06\% - 87.90\% at ES. Generally, plants at ES showed higher RWC than those at CS (Fig. 2d). RWC is associated with protoplasmic permeability in cells which causes loss of water and dissolved nutrients, resulting in early senescence of leaves (Masuch et al. 1988). More water in a leaf will help to maintain its physiological balance under stress condition of air pollution (Dedio 1975). Therefore the plants with high relative water content such as $T$. catappa under polluted conditions may be tolerant to pollutants.

\subsection{Air pollution tolerance index of the tree species}

Air pollution tolerance index (APTI) varied significantly with tree species $\left(F_{2,24}=97.88 ; P<0.01\right)$ and site $\left(F_{1,24}=45.69 ; P<0.01\right)$. There was also significant interaction of site with species for $\operatorname{APTI}\left(F_{2,24}=14.34 ; P<0.01\right)$ (Table 1a) indicating the environmental condition at the site had varying influence on the tree species. Decreasing order of APTI was T. catappa (15.66) $>$ A. occidentale (13.53) > T. grandis (13.17). Species at CS had higher APTI values than those at ES (Table $1 \mathrm{~b}$ and Table 2). According to the APTI classification, all tree species studied showed intermediate tolerance to pollution (Table 2). The APTI values in this study exceeded those reported by 
Ogunrotimi, et al. (2017); T. catappa (12.5), A. occidentale (10.7) T. grandis (12.1) in polluted urban areas of Ile-Ife, Osun state. Tak and Kakde, (2017) also reported lower APTI values for similar species in urban centres of India. Contrarily, Thakar and Mishra, (2010) reported higher APTI values than in the current study for A. occidentale (22.17) and T. grandis (20.97) growing around an Aluminium factory in Jharsuguda, India. Nayak, et al. (2015) also confirmed that Tectona grandis and Terminalia catappa showed intermediate sensitivity in polluted sites. Since species tolerance to pollution is best explained by their APTI value, it can be deduced that Terminalia catappa is most tolerant while Tectona grandis is least tolerant.

\section{Conclusions}

This study showed that assessment of tree species tolerance against air pollution using individual biochemical parameter (such as ascorbic acid, total chlorophyll, leaf extract $\mathrm{pH}$ or relative water content) alone may be misleading. For instance, Tectona grandis which showed the highest foliar $\mathrm{pH}$ and total chlorophyll concentration showed the least tolerance to air pollution (APTI). Based on the API assessment, T. catappa and Anarcadium occidentale are recommended to be used for greenbelt in polluted environments, such as vicinity of factories, as they proved to be good performers as opposed to Tectona grandis that performed only moderately.

\section{Acknowledgement}

The authors appreciate Mr. D. O. Jemirin, the Laboratory Technologist in the Department of Industrial Chemistry for assisting with the determination of biochemical parameters in the leaf samples. Comments from two anonymous RJS reviewers are acknowledged.

\section{References}

Agrawal M. 2005. Effects of air pollution on agriculture: An issue of national concern. National Academy of Science Letters 23(3\&4): 93-106.

Agrawal M. 1985. Plant factors as indicators of $\mathrm{SO}_{2}$ and $\mathrm{O}_{3}$ pollutants. In Biological Monitoring of the State of the Environment (Bioindicators). Indian National Science Academy, New Delhi, pp. 225-231.

Arnon DI. 1949. Copper enzymes in isolated chloroplasts polyphenol oxidase in Beta vulgaris. Plant Physiology 2(1):1-15.

Begum A, Harikrishna S. 2010. Evaluation of some tree species to absorb air pollutants in three industrial locations of South Bengaluru, India. European Journal of Chemistry 7: 151-156.

Cavanagh J-AE, Zawar-Reza P, Wilson JG. 2009. Spatial attenuation of ambient particulate matter air pollution within an urbanised native forest patch. Urban Forestry \& Urban Greening, 8:21-30 doi:http://dx.doi.org/10.1016/j.ufug.2008.10.002 
Dedio W. 1975. Water relations in wheat leaves as screening test for drought resistance. Canadian Journal of Plant Science 55(2), 369-378.

Escobedo F, Nowak DJ, Wagner J, De la Maza CL, Rodríguez M, Crane DE. 2008. Analyzing the cost-effectiveness of Santiago Chile's policy of using urban forests to improve air quality. Journal of Environmental Management 86: 148-157.

Flowers MD, Fiscus EL, Burkey S. 2007. Photosynthesis, chlorophyll fluorescence and yield of snap bean (Phaseolus vulgaris L.) genotypes differing in sensitivity to ozone. Environmental and Experimental Botany, 61: 190-198.

Gholami A, Mojiri A, Amini H. 2016. Investigation of the air pollution tolerance index (APTI) using some plant species in Ahvaz region. The Journal of Animal \& Plant Sciences 26(2): 475-480.

Gupta S, Nayek S, Bhattacharya P. 2011. Effect of air-borne heavy metals on the biochemical signature of tree species in an industrial region, with an emphasis on anticipated performance index. Chemistry and Ecology 27: 381-392.

Han Y, Wang QY, Han GH. 1995. The analysis about SOD activities in leaves of plants and resistance classification of them. Journal of Liaoning University (Natural Sciences Edition) 22: 71-74.

Hill AC. 1971. Vegetation: a sink for atmospheric pollutants. Journal of the Air Pollution Control Association 21:341-346

Hoque MA, Banu MNA, Okuma E. 2007. Exogenous proline and glycine betaine increase $\mathrm{NaCl}$ induced ascorbate-glutathione cycle enzymes activities, and proline improves salt tolerance more than glycinebetaine in tobacco bright yellow-2 suspension cultured cells. Journal of Plant Physiology 164: 1457-1468.

Klumpp G, Furlan CM, Domingos M. 2000. Response of stress indicators and growth parameters of Tibouchina pulchra Cogn, exposed to air and soil pollution near the industrial complex of Culoutao, Brazil. Science of the Total Environment 246:79-91.

Lima JS, Fernandez EB. 2000. Mangifera indica and Phaseolus vulgaris in the bioindicator of air pollution in Bahia, Brazil. Ecotoxicology and Environmental Safety 46(3): 275-278.

Liu Y-J, Ding H. 2008. Variation in air pollution tolerance index of plant near a steel factory; implications for landscape-plant species selection for industrial areas. WSEAS Transactions on Environment and Development 4(1): 24-32.

Lohe RN, Tyagi B, Singh V, Tyagi PK, Khanna DR, Bhutian R. 2015. A comparative study for air pollution tolerance index of some terrestrial plant species. Global Journal of Environmental Science and Management 1(4): 315-324.

Masuch G, Kicinski HC, Kettrup A, Boss KS. 1988. Single and combined effects of continuous and discontinuous $\mathrm{O}_{3}$ and $\mathrm{SO}_{2}$ emission on Norway spruce needless. 1. Historical and cytological changes. International Journal of Environmental Analytical Chemistry 32: 213241.

Mondal D, Gupta S, Datta JK. 2011. Anticipated performance index of some tree species considered for green belt development in urban area. International Research Journal of Plant Science 2(4): 99-106

Nayak D, Patel DP, Thakare HS, Satashiya K, Shrivastava PK. 2015. Evaluation of air pollution tolerance index of trees. Research in Environment and Life Sciences 8(1): 7-10.

Ninave SY, Chaudhaun PR, Gajghate DG, Tarar JT. 2001. Foliar biochemical features of plants as indicators of air pollution. Bulletin of Environmental Contamination and Toxicology 67: 133-140.

Odilara CA, Egwaikhide PA, Esekheigbe A, Emua SA. 2006. Air pollution tolerance indices (APTI) of some plant species around llupeju industrial area, Lagos. Journal of Engineering Science and Applications 4(2): 97-101.

Ogunkunle CO, Suleiman LB, Oyedeji S, Awotoye OO, Fatoba PO. 2015. Assessing the air pollution tolerance index and anticipated performance index of some tree species for biomonitoring environmental health. Agroforestry Systems 89(3): 447-454.

Ogunrotimi DG, Adereti FK, Eludoyin AO, Awotoye, OO. 2017. Urban air pollution control: selection of trees for ecological monitoring using anticipated performance indices in a 
medium-size urban area in Southwest Nigeria. Interdisciplinary Environmental Review 18(1): 40-54.

Ohamian EI. 2013. Scrap iron and steel recycling in Nigeria. Greener Journal of Environmental Sciences and Public Safety 2:1-9.

Omoju O. 2014. Environmental pollution is inevitable in developing countries. In: Breaking Energy, Climate Change Infrastructure International. Accessed at https://breakingenergy. com/2014/09/23/environmental-pollution-is-inevitable-in-developing-countries/

Padmavathi P, Cherukuri J, Reddy MA. 2013. Impact of air pollution on crops in the vicinity of a power plant: a case study. International Journal of Engineering Research and Technology 2(12): 3641-3651.

Prajapati SK, Tripathi BD. 2008. Anticipated performance index of some tree species considered for green belt development in and around an urban area: a case study of Varaasi city, India. Journal of Environment Management 88:1343-1349.

Prusty BAK, Mishra PC, Azeez PA. 2005. Dust accumulation and leaf pigment content in vegetation near the National Highway at SBP, Orissa, India. Ecotoxicology and Environmental Safety 60: 228-235.

Rajamanickam R, Nagan S. 2018. Assessment of air quality index for cities and major towns in Tamil Nadu, India. Journal of Civil and Environmental Engineering 8: 304. doi: 10.4172/2165-784X.1000304

Rao DN. 1977. Use of plants as indicators and monitors of $\mathrm{SO}_{2}$ pollution. Chemical Age of India 28: 665-672

Scholz F, Reck S. 1977. Effects of acids on forest trees as measured by titration invitro inheritance of buffering capacity in Picea- Abies. Water, Air Soil Pollution 8(1): 41-45.

Singh SK, Rao DN. 1983. Evaluation of plants for their tolerance to air pollution. In: Proceedings of Symposium on Air Pollution Control, Indian Association for Air pollution Control, New Delhi, India, pp. 218-224.

Singh SK, Rao DN, Agrawal M, Pandey J, Narayan D. 1991. Air pollution tolerance index of plants. Journal of Environmental Management 32: 45-55.

Singare PU, Talpade MS.2012. Physiological responses of some plant species as a bio-indicator of roadside automobile pollution stress using the air pollution tolerance index approach. International Journal of Plant Research 3(2): 9-16.

Tak AA, Kakde UB. 2017. Assessment of air pollution tolerance index of plants: a comparative study. International Journal of Pharmacy and Pharmaceutical Sciences 9(7): 83-89.

Thakar BK, Mishra PC. 2010. Dust collection potential and air pollution tolerance index of tree vegetation around Vedanta Aluminium Limited, Jharsuguda. The Bioscan 3: 603-612.

Tiwari S, Bansal S, Rai S. 1993. Air pollution tolerance index of some plants in urban areas of Bhopal. Advanced Ecologia 16(1): 1-8.

Tripathi AK, Gautam M. 2007. Biochemical parameters of plants as indicators of air pollution. Journal of Environmental Biology 28(1): 127-132.

Varshney SRK, Varshney CK. 1984. Effects of Sulphur dioxide on ascorbic acid in crop plants. Environmental Pollution 35(4): 285-290. 